This PDF is a selection from a published volume from the National Bureau of Economic Research

Volume Title: Founding Choices: American Economic Policy in the 1790 s

Volume Author/Editor: Douglas Irwin and Richard Sylla, editors

Volume Publisher: University of Chicago Press

Volume ISBN: 0-226-38474-8 (cloth); 0-226-38475-6 (paper)

ISBN13: 978-0-226-38474-0 (cloth); 978-0-226-38475-7 (paper)

Volume URL: http://www.nber.org/books/irwi09-1

Conference Date: May 8-9, 2009

Publication Date: December 2010

Chapter Title: The Constitutional Choices of 1787 and Their Consequences

Chapter Authors: Sonia Mittal, Jack N. Rakove, Barry R.

Weingast

Chapter URL: http://www.nber.org/chapters/c11736

Chapter pages in book: (25 - 56) 


\title{
The Constitutional Choices of 1787 and Their Consequences
}

\author{
Sonia Mittal, Jack N. Rakove, and Barry R. Weingast
}

\subsection{Introduction}

The choices made in the creation of a constitution have immediate political results and, often enough, lasting economic consequences. That, at least, is the overall thesis of this book, which examines the economic significance of the Federal Constitution drafted in Philadelphia in the late spring and summer of 1787. The Constitution occupies so large a place in our collective understanding of American history and politics, and is so vital a symbol of national identity that it is difficult to recall that the American federal republic might easily have evolved along alternative paths. Of course, it is well known that some matters were hotly contested in 1787 , such as the disputes over representation that dominated the first seven weeks of debate at Philadelphia, and that others, notably the absence of a declaration of fundamental rights, became objects of public controversy as soon as the Constitution was submitted to a sovereign people for ratification. But to emphasize the big dramatic issues - the purported "great compromise" over representation, the assuaging of Anti-Federalist doubts with the proposal of a "bill of rights" - is still only to confirm what a heroic episode it all was. Other contingent choices that set the Convention on its course, or that gave the Constitution its essential ability to endure, remain obscure.

In this chapter, we treat three interrelated issues involving the constitu-

Sonia Mittal is a PhD candidate in political science at Stanford University. Jack N. Rakove is the William Robertson Coe Professor of History and American Studies and professor of political science at Stanford University. Barry R. Weingast is the Ward C. Krebs Family Professor in the department of political science at Stanford University, and a senior fellow at the Hoover Institution.

The authors gratefully acknowledge John Carey, Farley Grubb, Douglas Irwin, Pauline Maier, and John Wallis for helpful conversations. 
tional choices of 1787. First, we examine various defects of the Articles of Confederation, including basic institutional failures and their consequences for public policy. Several features of the Articles made enforcement of federal measures virtually impossible, and thus hindered the capacity of the national government to adapt to unforeseen circumstances. An array of crises emerged under this political system, many associated with states that had incentives to shirk their federal obligations and pursue their self-interest at the expense of the common good. The lack of reliable and independent sources of revenue left the national government financially dependent on the states. Similar problems emerged in other policy domains: foreign relations, internal trade barriers, and paper money. Congress under the Articles also failed to solve other problems, such as enforcing the Treaty of Paris, the British closure of its Caribbean ports to American ships, and asserting control over the western frontier. Retiring the public debt and establishing public credit remained major difficulties. Even as these problems became clear, the Article's institutional constraints prevented their resolution. The unanimity rule necessary to revise the Articles rendered amendment and adaptation of its institutions impossible. Try as they might, advocates of greater powers for the national government could not convince every state to go along.

Second, we emphasize that the dramatic paradigm shift inherent in the adoption of the Constitution - from a federal union premised on the voluntary compliance of the states with federal measures to one in which two governments would each act legally on their common citizenry - was not inevitable. Instead, it was one choice among many. The Founders could easily have followed a less risky strategy by proposing more limited though still significant adjustments within the framework of the Articles. That they did not ultimately pursue this path reflects their understanding of the Articles' failures and the drastic change needed in any future constitutional solution. Equally important, the framers' success was not inevitable. Institutional innovations incorporated into the Federal Constitution of 1787 were new and untested. Although it is easy for us to believe that more than two centuries of relative political stability means that success was inevitable, the history of previous confederations and republics suggests otherwise. ${ }^{1}$ A stable republican constitution capable of governing a society as large as the United States, for example, had never existed.

Finally, we examine how the Constitution's features allowed Americans both to solve the wide range of policy problems and to adapt policy and institutions as circumstances required. The new Constitution had effects on policies on two levels: directly, reflecting the national government's addressing various problems under its new authority; and indirectly, reflecting the

1. In making this claim, we do not, of course, overlook the dark and bloody ground of the Civil War or the major shift in federal relations to which it led. However, we see that conflict not as a constitutional failure per se, but rather as a crisis rooted in two fundamentally incompatible visions of the nature and value of the federal Union itself. 
states acting to address other problems within the context of the newly created market-preserving federalism. ${ }^{2}$ For our purposes, two of the most important institutional innovations include the replacement of the unicameral consultative Continental Congress by a true bicameral legislature, and the shift toward a centralized federalism to replace the decentralized system of the Confederation. ${ }^{3}$ In contrast to the Articles, the new constitutional system proved remarkably adaptable, allowing the nation to confront new challenges. As an illustration of both the successes and limitations of this system, we discuss the persistent problem of slavery in the antebellum years.

This chapter proceeds as follows. In section 1.2 we reconstruct the larger realm of constitutional choice that shaped the deliberations of 1787 , and then reflect on the lasting significance for American economic development of key decisions that were taken. In section 1.3, we turn to the consequences of the Constitution, both direct and indirect. This discussion begins with the new policies chosen to address the various policy dilemmas under the Articles, turns to the consequences of the new centralized federalism, and then ends with the long-term consequences of the ability to adapt, including a special look at the ongoing difficult problem of slavery within the republic. Section 1.4 concludes.

\subsection{The Road to Philadelphia}

Once past the opening words of the preamble, the Constitution is a prosaic text. Most of its clauses are devoted to allocating different powers and duties among the great departments of government, sketching the relationship and boundaries between national and state governments, describing the modes of appointment of particular officers, and detailing their terms of service. Yet the larger enterprise of constitution-making cannot be wholly reduced to the sum of these provisions. Or rather, these provisions, properly construed, illuminate the multiple dimensions of the American constitutional project of the late 1780s. Four dimensions deserve particular notice.

First, the immediate occasion for the calling of the Convention was the perceived need to establish a new framework within which key public policy and public goods problems of the 1780s could be adequately addressed and satisfactorily resolved. Those problems were primarily consequences of the war for independence and the immediate aftermath of the treaty of peace (Edling 2003; Marks 1986; Rakove 1979).

A short list of these specific policy concerns include at least the following:

2. Market-preserving federalism is a type of federalism that places states in competition with one another in the context of policy and tax authority over local public goods while requiring them to face the financial consequences of their decisions (i.e., the hard budget constraint); see Weingast (1995).

3. Riker (1987) describes the American invention of centralized federalism in 1787. 
- Providing the national government with independent and reliable sources of revenue to meet its basic expenses.

- Funding or retiring the public debt accrued during the war, thereby enabling the United States to have future access to credit markets at home, but especially abroad.

- Developing effective strategies for responding to the twin economic threats to postwar prosperity: the flooding of American markets with European goods, and the closure of British harbors, particularly in the West Indies, to American merchantmen.

- Enforcing key provisions of the Treaty of Paris relating to the rights of British creditors seeking payment of prewar debts and loyalists seeking recovery of confiscated estates.

- Securing effective control of the new national domain above the Ohio River and maintaining the political loyalty of trans-Appalachian settlers more generally, especially after Spain closed the Mississippi River to American navigation in 1784.

Many of these problems stemmed from the incentives of states to shirk their duties rather than cooperate. Insufficient coercive power under the Articles led to shirking by the states. States, for example, faced free-rider incentives to limit their tax collection for the national government. The national government had no means to ensure cooperation or to punish states that shirked. Similar problems arose in other areas, such as honoring treating obligations, internal trade barriers, and paper money.

Together, these five clusters of issues defined the issue space within which questions of public goods and public policy began to converge with issues of constitutional authority and institutional design. Absent these specific concerns, there would have been no occasion for anything like the Federal Convention to be held. But even with them, the putative reformers favoring a stronger federal union had to ask whether their optimal strategy was one of piecemeal amendment or wholesale revision of the Articles of Confederation. Until early 1786, political prudence favored the idea of gradual change; by the close of the year, political desperation tipped the calculation toward comprehensive change. Yet, had the delegates who straggled into Philadelphia in May 1787 acted more cautiously, many contemporaries would have applauded their good judgment in not making the best the enemy of the good.

A second major dimension of the constitution-making project of the late 1780 s is that it involved a substantial rethinking of the republican assumptions that informed the drafting, a decade earlier, of both the initial state constitutions that replaced the ancien regime of colonial government and the Articles of Confederation. This rethinking is what gives the constitutional debates of 1787 to 1788 - both the deliberations at Philadelphia and the broader public discussion that followed - their dramatic character and intel- 
lectual significance. To draft the Constitution and to secure its ratification, the framers and their Federalist supporters had to challenge basic premises under which the revolutionaries had acted a decade earlier (Wood 1969). Part of that challenge was directed, of course, to such classic questions as the optimal size of republics or the degree of virtue necessary to their preservation. But a substantial part focused on basic matters of institutional competence and constitutional design - that is, to the real stuff of the practical constitution-making enterprise.

Third, that enterprise was also a negotiated compact among a preexisting set of established polities. Whether the original states are better described as fully sovereign entities or, more narrowly, as autonomous jurisdictions for purposes of internal governance, their delegates at Philadelphia and the subsequent ratification conventions did not operate behind any veil of political ignorance when it came to assessing how adoption of the Constitution might affect vital interests. The Convention's compromises over the composition and election of the political branches were only the most obvious examples of the bargaining process that went into constitution-making. The Constitution also operated as a mutual security pact among the existing states, sharply limiting their capacity to threaten each other militarily. Equally important, the Constitution also collectively assured the territorial integrity of the states against separatist movements within their claimed boundaries (Onuf 1983; Hendrickson 2006).

But, in the fourth place, those states - or rather, their governments - were no longer the sole or even primary parties to the federal compact being renegotiated. Nor was the Constitution simply an agreement to be promulgated by a group of dignitaries once they had resolved all the questions their deliberations had raised. For the Constitution to become fully constitutional, it also had to be ratified by the people themselves, acting through popularly elected conventions in each of the states. The relative ease with which this new rule of ratification was adopted and applied, and the Federalist success in restricting the true decisions of these conventions to up-or-down votes on the Constitution in its entirety, guaranteed that the new system of government would begin its operation with a remarkable measure of legitimacy (Rakove 1996; Siemers 2002). As passionately as Americans would soon begin debating the meaning of particular clauses, their disputes never denied the legitimacy of the constitutional revolution of 1787 to 1788 . That was not an outcome that could have been taken completely for granted when the movement for constitutional reform risked the calling of a general convention, or even after the luminaries at Philadelphia finished their work.

To survey these multiple facets of constitution-making is to identify one final aspect of the great enterprise of 1787 . No obvious, transparent agenda was destined or predetermined for the Convention to pursue; but, instead, a range of possible outcomes existed among which choices had to be made. The otherwise rich documentary record of the debates of 1787 to 1789 is 
strikingly thin when it comes to knowing what either the delegates themselves or the American public initially expected the Convention to accomplish. The one great exception to this is the evidence we have for James Madison's preparations for Philadelphia, and given his key role in setting its agenda, that evidence goes far toward explaining why the Convention took the course it did. ${ }^{4}$

Even so, it is important to stress that multiple paths of constitutional reform were available in 1787 . The Convention could have easily pursued a more prudent path. Nor should one forget that the logic of radical reform in 1787 also rested on the perceived "imbecility" of the Articles of Confederation, especially as manifested in the absurd rule requiring the unanimous approval of the state legislatures for its amendment. Had any of the amendments to the Confederation previously proposed surmounted that obstacle, the case for an extraordinary plenary convention might never have been made, much less prevailed at that time. The American Union could then have evolved along any number of counterfactual paths. But the fact remains, the contingencies of historical action did break one way, not another, and fundamental choices were made. Not least among them was the decision to abandon the framework of the Confederation and to proceed with radically different notions of the institutional structure and legal authority of the Union.

\subsubsection{The Initial Agenda of Constitutional Reform}

Drafted in 1776 to 1777, the Articles of Confederation reflected the dominant republican assumptions that also shaped the first state constitutions. Overall coordination of the struggle for independence belonged to Congress; the states would implement its decisions, acting not as sovereign judges of the propriety of its resolutions, but as administrative auxiliaries with superior knowledge of local conditions and the representative political authority to rule by law. This understanding accorded well with American experience. Governance in colonial America had always been highly decentralized; the authority of the empire never penetrated into the countryside, and there was no national administrative apparatus to speak of. Congress itself was a badly undermanned institution. Its members typically served some months during a yearly term or two before insisting that others bear the burden of long absences from home and family. It made completely good sense to expect the states to do the real work of mobilizing the country's resources for war. ${ }^{5}$

4. See Rakove (1996, chapter 3); but for a characteristically provocative and perverse dissent on just this point, counterfactual, see McDonald $(1985,205)$.

5 . Which is not to say that all states were equally competent in mobilizing those resources. See the provocative comparison of the capacities of northern and southern states in Einhorn (2006). The best single study of how an individual state went about complying with federal measures is Buel (1980). 
This expectation that the states would strive to do their duty also rested, Madison rightly recalled, "on a mistaken confidence that the justice, the good faith, the honor, the sound policy, of the several legislative assemblies would render superfluous any appeal to the ordinary motives by which the laws secure the obedience of individuals" (Madison 1787). The first American federalism was thus grounded on the public-spirited values of republicanism, and those values were sorely tested by the duration of a bitterly fought war and the enormous strain it placed on both the capacity of the states and the virtue of their citizens.

By 1780 the discouraging results of this test were apparent. Such efforts as the states made to levy taxes were clearly inadequate to meet the openended demands of the war. One response to this continuing shortfall was to rely on the customary methods of currency finance, printing money and trying to withdraw it from circulation before it depreciated too badly. But depreciation occurred regardless, and in 1779 the specie value of the continental dollar fell to 20:1. In that year, Congress made the painful decision, first to stop printing money, and then to adopt a new requisitioning system of "specific supplies" to be demanded from particular states (Rakove 1979). The fits and starts of that conversion, compounded by the worst snowfalls in decades, made the winter of 1780 the absolute nadir of the war effort.

It was also the moment from which we can date the emergence of the reformist impulses that ultimately led to the Federal Convention of 1787. Perhaps it is only a symbolic coincidence that Madison entered Congress in March 1780, or that a few months later Alexander Hamilton drafted the mini-treatise on political economy (as a letter to New York delegate James Duane) that first exhibited his keen financial intelligence. More noteworthy is the fact that members of the national political elite already recognized that the still-unratified Articles of Confederation were inadequate to the real problems of governance the war had exposed. Thus, even as Congress worked to bring Maryland, the last holdout, to end its dissent, delegates like Madison were already contemplating the amendments needed to give Congress adequate authority.

After Maryland ratified the Confederation early in 1781, Congress quickly sent its first amendment to the states, requesting permission to levy a 5 percent impost on foreign imports, meant not as a source of operating revenue, but as security against which Congress might attract foreign loans. Congress also appointed Robert Morris as its first (and only) superintendent of finance. Amid his heroic labors in keeping the Continental Army in the field in advance of the decisive victory at Yorktown, Morris found time to begin drafting a comprehensive program to secure adequate revenues and establish public credit. When Rhode Island effectively killed the impost in 1781, the Morris program to vest Congress with authority to levy land, poll, and excise taxes became the basis for months of sharp debate and political maneuvers. To pressure Congress to adopt his program, Morris attempted 
to mobilize public creditors throughout the states while exploiting unrest in the army. Morris overplayed his hand, however, and eventually lost the support of a key bloc of delegates who joined Madison in promoting a compromise measure. The states would be asked to assign permanent revenues of their own choosing to Congress, a new impost would be proposed, and the unwieldy formula of the Confederation for apportioning the common expenses of the Union on the basis of the assessed value of improved land would be replaced by a simple population rule (with slaves counting as threefifths of free persons). This was the basis for the package of resolutions that Congress sent to the states on April 18, 1783, and it marked the first major component of the agenda of federal constitutional reform.

Over the course of the next year, two other sets of issues emerged to enlarge the potential agenda for constitutional reform. One was concerned with the dual crises that afflicted American commerce in the first year of peace, when scores of British ships entered American harbors, bringing imported goods war-deprived consumers were all too happy to purchase, to the detriment of local artisans, while London simultaneously barred American merchantmen from imperial harbors, most importantly in the West Indies, the traditional market for American agricultural surpluses. A second set of issues had to do with the effective governance and political control of the trans-Appalachian interior. Above the Ohio River, Congress gained title to a national domain established through the voluntary cessions of states claiming interior lands. Its ability to develop this land, however, was threatened by several factors: the free flow of squatter-settlers into southern Ohio, opposition from indigenous peoples who were surprised to learn that they had just been defeated in the Revolutionary war, and the retention by the British of frontier forts from which they could encourage resident tribes to resist American expansion. Below the Ohio, the future states of Kentucky and Tennessee were still part of Virginia and North Carolina, respectively, but settlers there were deeply troubled by the Spanish decision to prohibit the transshipment of American produce through New Orleans into the Gulf of Mexico. If Congress could not find a way to relax the Spanish choke hold, the loyalty of these settlers would be up for grabs, and the United States might forfeit the generous territorial settlement it had gained in the peace negotiations of 1782 and 1783.

In April 1784, Congress responded to the first set of issues by asking the states to approve two additional amendments to the Confederation. Stopping well short of recommending a plenary power to regulate foreign trade, these proposals would have empowered Congress to retaliate against nations that discriminated against American merchants. In dealing with the new national domain, Congress adopted a land ordinance (forerunner to the Northwest Ordinance of 1787) that anticipated the eventual admission to the Union of a number of new states, on essential conditions of equal- 
ity with its original members. That was a visionary statement of a core constitutional principle of state equality, and one which promised that the interior of the continent would not be developed as internal colonies of the older societies on the seaboard. But the greater challenge Congress faced in the west stemmed from its inability to project national power beyond the Appalachians. Without the resources to maintain armed forces in the Ohio Valley, there was little chance that Congress could overawe either squattersettlers or the Indians they were antagonizing, much less induce Spain to open the Mississippi to American navigation.

In the end, then, it all (or mostly) came down to revenue, and from 1783 to 1786 , that prospect in turn depended on unanimous state acceptance of the package of amendments Congress had proposed in April 1783. The basic obstacle to reform remained the unanimity rule of the Confederation, a rule predicated in part on the belief that the states were quasi-sovereign jurisdictions, but also fortified by the perception that republican convictions of the public good should make consensus attainable. Whether decisions about essential public goods should require that high a degree of agreement was the great question that the mid-decade constitutional stalemate left unresolved. Insofar as the failure to attain unanimity challenged core republican assumptions, the stringent rule of amendment worked to make calculations of interest rather than appeals to virtue the denominator of American politics. The unanimity rule of the Articles greatly limited the ability of Americans to adapt to new circumstances and to adjust their institutions as practice diverged from expectations.

\subsubsection{Madison's Agenda}

Taken individually or collectively, none of these measures portended a radical shift in the character or structure of the Confederation. Well into 1785 , the agenda of constitutional reform remained gradualist, not radical. All of the powers being considered could be vested in the same unicameral body that had governed national affairs since 1774 . Nationally minded politicians hoped that the specter of an "imbecile" Congress (as it was often disparaged) and the bite of commercial depression would somehow enable Americans to recognize that an assembly appointed by their own state legislatures did not pose the same dangers as a distant Parliament once had.

For this strategy to succeed, however, success had to begin somewhere, and in practice the unanimity rule of the Confederation made its amendment impossible. As the nation seemed to sink into commercial depression by 1785 , a committee of Congress, led by James Monroe, drafted yet another amendment giving Congress the sole power "of regulating the trade of the States, as well with foreign Nations, as with each other," including authority to levy "such imposts and duties upon imports and exports, as may be necessary for the purpose," with the resulting revenues accruing to 
the states in which they were collected (Ford 1904-37, 494). But with the previous amendments still in limbo, it seemed pointless to add a fresh one to the queue.

These issues of revenue and public credit, foreign commerce, and control of the interior remained the great national questions. But within the states, other developments were taking place that would ultimately lead to a significant expansion in the agenda of constitutional reform. The most important of these concerned efforts by individual states to retire their own public debts and to remove the financial detritus of the war. That involved imposing higher levels of taxation than an exhausted population was inclined to favor, and amid the depressed economic conditions of the mid-1780s, calls for tax and debtor relief and the issuance of paper money were hardly surprising. As these demands mounted, and as the politics of individual states - notably Rhode Island - came under the sway of pro-paper money factions, stalwart defenders of basic property rights persuaded themselves that the republic was endangered by what we might call economic populism avant le fait. If the advocates of paper money prevailed now, they worried, who could guarantee that the American people might not come to favor a confiscatory redistribution of other forms of wealth as well, even an Agrarian law modeled on the precedent of Roman antiquity and a radical strain in modern republican thinking that ran from More and Machiavelli to Harrington and Locke and even, perhaps, to Jefferson (Holton 2007; Nelson 2004).

No one was more alarmed over these developments than Madison, and in our view, his key role in shaping the ultimate agenda of constitutional reform makes close attention to his developing views a key element in any account of what happened in 1787. There is no question that a brooding concern over the security of the rights of creditors and landowners helped inspire Madison's efforts to rethink the basic premises of republican government (Rakove 1996). Scholars who equate his originality as a constitutional thinker solely with the "extended republic" and "ambition counteracting ambition" hypotheses of Federalist 10 and 51 overlook the extent to which the real source of his creative insights lay in his acute analysis of the institutional workings and defective outputs of state legislatures. Two years of service in the Virginia assembly, after he had been term-limited out of Congress in 1783, turned Madison into a keen student of the science of legislation, especially as that applied science was practiced, not by the all-wise "lawgiver" of Enlightenment philosophy, but by rustic provincials who were prone to error and all too responsive to the parochial concerns of their constituents. By August 1785, he was convinced that the crying need of republican government within the states was to find ways to "give wisdom and steadiness to legislation" (Rakove 1999). This need was closely tied to his emerging recognition, as he would state it in Federalist 10, that "The regulation of these various and interfering [economic] interests forms the principal task of modern legislation, and involves the spirit of party and faction in 
the necessary and ordinary operations of the government" (Cooke 1961a, 59). From this concern evolved the critical conviction that no solution to the problems of federalism would be complete that did not reach the matter of legislative misrule within the states.

Whether that concern would ever become the basis for action, however, depended on the uncertain fate of the amendments of 1783 and 1784. In late January 1786, the Virginia legislature invited other states to join it in sending delegates to a special convention to consider the nation's commercial woes. Though Madison was initially a reluctant supporter of this scheme, he soon concluded that this meeting offered a more promising path to constitutional reform than adherence to the rules of the Confederation. From his correspondent James Monroe, he knew that Congress was considering yet another set of amendments to the Articles. But believing that Congress itself was too politically discredited to be an agent of its own transformation, Madison agreed that other steps were necessary.

Had the eventual Annapolis convention of September 1786 been better attended, it might have framed a new and more expansive amendment vesting broad commercial powers in Congress; akin, perhaps, to the recommendation Monroe's committee had prepared in 1785, or to similar proposals that were presented to Congress in the summer of 1786. But the dozen commissioners from five states who quaffed a few tankards at Mann's Tavern in mid-September 1786 were too small a gathering to propose anything of their own authority. Rather than adjourn empty-handed, however, they seized upon a clause in the credentials for the New Jersey deputies, and proposed instead that a new meeting be held at Philadelphia the following May. That call was eventually heeded by every state except Rhode Island and endorsed by Congress as well.

In the winter and early spring of 1787 , Madison set about preparing a working agenda for the Philadelphia meeting. Much has been written about the extent to which this course of reading and reflection led him to hypothesize that a large diverse republic might better resist the "mischiefs of faction" than the small, homogeneous nurseries of disinterested civic virtue beloved of traditional republican theorists. But for purposes of framing an agenda for action, other aspects of Madison's reflections and preparations appear more consequential.

First, and arguably most important, Madison concluded that any system of federalism grounded on the voluntary compliance of the state governments with national measures was doomed to failure. ${ }^{6}$ As independent jurisdictions, the interests of the states were too disparate, and their politics too prone to manipulation by "courtiers of popularity," to be expected to

6. As mentioned earlier, Madison clearly perceived the commitment problem at the heart of state shirking. "A distrust of the voluntary compliance of each other may prevent the compliance of any, although it should be the latent disposition of all" (Madison 1787, 73). 
comply regularly and enthusiastically with the recommendations of a toothless Congress. Even when their interests should coincide, doubts about their mutual good faith in fulfilling federal obligations would discourage active compliance. It followed that the national government had to be empowered to operate as all true governments do, with constitutional authority to enact, administer, and adjudicate its own laws, which would apply directly to citizens and involve the state governments as little as possible. That, in turn, meant replacing the unicameral Continental Congress with a bicameral legislature while also creating a constitutionally independent executive and judiciary. (Here is where the lessons to be drawn from the experience of republican government in the states would prove most salient.)

Second, Madison's rich critique of the "Vices of the Political System of the U. States" (1787) indicted the shortcomings of state-based politics on additional grounds. States were defaulting on their federal duties in other ways: by arrogating congressional authority; violating international treaty obligations (especially by obstructing British creditors seeking recovery of prewar debts); trespassing on each other's rights (his leading example being the designation of paper money as legal tender); and by showing a "want of concert in matters where common interest requires it," a "defect [that] is strongly illustrated in the state of our commercial affairs" (Madison 1787, 69-71). Implicit in this list of criticisms was the idea that constitutional reform had to extend beyond the principal purpose of making the Union independent of the states. It required as well an effort to curtail the authority of the states themselves, especially as their residual sovereignty constrained the pursuit of national objects or the harmony of interstate relations.

Third, Madison's analysis extended to the internal vicissitudes of state policy, or what he called the "multiplicity," "mutability," "injustice," and "impotence" of state lawmaking. It would not be enough, he concluded, to restrict the states from jeopardizing the pursuit and attainment of common interests. It was also essential to check their legislative excesses - to provide a federal remedy, through a congressional negative on state laws, that could check the factious forces swirling through state politics. That negative could be deployed defensively, to block the states from adopting measures that threatened federal policies and national interests. But it could also be used for interventionist purposes, to protect individuals and minorities against the unjust or ill-considered laws that dominant majorities were likely to adopt. And there is no question that the class of legislation that most worried, indeed obsessed Madison was the quasi-populist, anticreditor, prorelief measures that various states had either adopted or were still discussing (Rakove 1996; Holton 2007).

Fourth, all of Madison's concerns at this critical moment rested on a perception that the future politics of the republic would pivot around efforts by interests - whether defined in terms of communities, classes, or occupations - to exploit the positive lawmaking authority of both state and na- 
tional governments for their own purposes. Today this seems like a truism, and wholly unsurprising. But in the eighteenth century, the reigning political ideology viewed representative assemblies first and foremost as checking institutions, not as the adaptive and preference-aggregating forums they were in the process of becoming. Madison, by contrast, had developed an acutely modern notion of legislation. Drawing in part on the experience of wartime governance, but accurately foreseeing the more active use of legislative power in an age of economic development and improvement, he was deeply concerned with promoting the proper use of legislative power. In the states, where the bulk of economic regulation would still take place, it was important to guard against the dominance of factious, self-interested majorities. At the national level, however, it might be possible, through the refining mechanisms of election and deliberation, to promote a more considered, less impulsive understanding of the "public good." His notion of what the particular public goods comprising the broader public good of res publica might consist of was probably less expansive or complex than that of his northern counterparts, particularly his current ally and future rival, Alexander Hamilton. But the idea of improving the quality of legislative deliberation through the election of a superior class of representatives was premised on the belief that republican governments would be active governments capable of responding effectively to a wide variety of challenges through informed processes of collective deliberation.

\subsubsection{At Philadelphia}

In the eight months between the Annapolis and Philadelphia conventions, there must have been many private conversations about the potential agenda for constitutional reform. It was "not uncommon," treasury commissioner Samuel Osgood wrote John Adams, "to hear the principles of Government stated in common Conversation. Emperors, Kings, Stadtholders, Governors General, with a Senate, or House of lords, \& House of Commons, are frequently the Topics of Conversation." Some favor "abolishing all the state Governments" and "establishing some Kind of general Government," Osgood added, "but I believe very few agree in the general Principles; much less in the Details of such a Government" (Rakove 1979, 387). Absent a preConvention planning conference in which proto-Federalist notables could have mapped strategy, and given the lack of published speculation as to what the Convention might do, the extent to which Madison's own preparations ultimately mattered in shaping the agenda of discussion becomes more evident. Short of abolishing the states outright, or impracticably trying to equalize their net influence by a creative redrawing of state boundaries, it is difficult to conceive how anyone could have fashioned a more expansive agenda than Madison worked out in the roughly two months preceding the appointed meeting day of May 14.

Having issued the original invitation to Philadelphia, the Virginians were 
punctual about attending. The same could not be said for the other delegations. While waiting for their arrival, the Virginians crafted the fifteen articles that Governor Edmund Randolph introduced as the Virginia Plan on May 29. In contrast to all prior discussions of constitutional reform, which had focused on the specific additional powers the Union was deemed to need, the Virginia Plan was far more concerned with structure than authority. Article 6 would empower the new bicameral legislature "to legislate in all cases to which the separate States are incompetent, or in which the harmony of the United States may be interrupted by the exercise of individual Legislation" (Farrand 1966, I, 21). Although it is possible that the Virginians really did intend to vest a future congress with this kind of plenary power, it seems more likely that this formula was meant to serve as a placeholder whose contents would be specified later, once the great disputes over representation that consumed the first seven weeks of debate were resolved. Madison's political strategy was to insist that the Convention must first agree that representation in both houses of the legislature had to be proportioned to population, and that the quantum of power the large states would be willing to vest in the new government depended on the satisfactory resolution of this issue.

That strategy held even after William Paterson proposed the New Jersey Plan in mid-June. Although this plan's provisions were more reminiscent of the kinds of reforms that had been discussed over the past few years, this alternative scheme proved a brief distraction from the debates over representation. Once the New Jersey Plan was dispatched, the convention spent another four weeks trying to solve the representation conundrum. The basic story is familiar to every schoolchild: a good compromise was finally struck allowing the fearful small states to preserve an equal vote in the Senate, while an evil but perhaps necessary bargain enabled the slaveholding states of the South to count their human chattel for purposes of representation. Often overlooked in this moral calculus is the reality that slavery was the real, material, palpable interest that had to be accommodated if a lasting, intersectional Union was to be created, and with it the benefits of economic integration the Constitution was intended to promote. The ostensible conflict between small and large states, by contrast, was ephemeral and false, since the size of the state in which one works and votes has never identified an actual interest deserving or requiring promotion (Rakove 1996, 57-93).

Once the twin issues of representation were resolved in mid-July, the delegates were finally free to turn their attention to what they actually wanted the government to do. That task was entrusted to the committee of detail that met during the ten-day adjournment from July 26 to August 6. Its report marked the point at which the open-ended grant of legislative power in the Virginia Plan began to be transformed into the enumerated Article I, Section 8 powers of the final draft.

Once the Convention took up the committee's proposals, the ensuing disagreements on matters of substance were few. Vesting Congress with the 
power to levy and collect taxes and regulate foreign and interstate commerce were foregone conclusions. On economic matters, the two main sticking points were the prohibition of taxes on exports and the proposal that navigation acts-laws regulating foreign commerce - require two-thirds majorities in both houses. There were some sharp exchanges on both points, but the convention found little difficulty in treating the retention of the prohibition as a concession to the commodity-exporting states of the South, and eliminating the two-thirds requirement as a fair bargain with the commercial North.

One other matter would prove a source of significant controversy after the Constitution was ratified. On August 18, Madison included among a list of further legislative powers to be considered the power "To grant charters of incorporation in cases where the Public good may require them, and the authority of a single State may be incompetent." That same day, Charles Pinckney proposed a simpler version of the same power, dropping Madison's qualifying phrases (Farrand 1966, II, 325). When the committee of detail and the committee on postponed parts failed to report a suitable clause, Madison renewed his motion on September 14, three days before the Convention adjourned. After brief debate, the motion failed, eight states to three. Madison could reasonably infer that the Convention had thereby denied Congress the power in question. A few years later he learned he was wrong, and that the Necessary and Proper Clause was capacious enough to fill the textual gap — or so Secretary of the Treasury Hamilton said, and President Washington finally agreed.

Compared to the lengthy debates over representation in June and July, many a scholar has wished that the delegates could have spent more time in August and September hashing out their ideas of what they expected the new national government, if ratified, to do. There are notable differences between the extended speeches of the first weeks of deliberation, and the more concise and clipped exchanges of August and early September. Perhaps Madison's exhaustion as the consensus note taker explains part of the discrepancy, but it is just as plausible to think that the later debates took the form they did because the delegates were already deeply united in their notions of the expanded powers the Union should exercise.

\subsection{The Constitution's Effects}

As section 1.2 suggested, perhaps the most striking contribution of the Constitution - and one too often taken for granted - was the creation of a successful, stable, republican government: a national government at once responsive to the interests of citizens, yet limited in scope and capable of respecting a wide range of rights. Without this accomplishment, the United States is unlikely to have achieved its long-term history of economic growth over the next two centuries. Moreover, this form of government was a major 
new invention: a stable republican government over an extended territory as large as the United States had never before existed, and many thought it impossible.

The Constitution, however, did not create a competitive polity and a competitive market economy. Long-term economic growth did not automatically follow. Only in the most general sense did the Constitution create "a machine that would go of itself" (Kammen 1986). To survive and thrive in an uncertain and ever-changing world, Americans had to solve a host of important economic and political problems. This required that they devise a variety of new institutions, frameworks, and policies, including national defense; financial markets; policies with respect to trade, intellectual property rights, land, labor, money, and bankruptcy; the promotion of economic growth through public goods and infrastructure; education; political, economic, and geographic expansion; and the one problem that would prove the most difficult to manage, sectional conflict.

In a real sense, therefore, the Constitution's most important accomplishment was to create a framework within which Americans could cooperate to devise the institutions and policies necessary to support economic and political development, resolving various threats to cooperative activity as they arose (Mittal [2010, 2008]; also see Landau [1973, 1969]).

The Constitution's most general direct economic effect was to create a common market and the basis for specialization and exchange that emerged over the next two generations. As North (1961) argued, over the first generation under the Constitution, economic producers in different regions came to specialize in different economic activities. The South produced export crops (originally tobacco, rice, and indigo; later sugar, and especially cotton). The Northeast concentrated on transportation and financial services for southern exports (financing of exports, insurance, marketing, and the transportation of exports). The Northwest, largely independent at first, increasingly specialized in the production of food, shipped south along the waterways and, once the transportation infrastructure grew, shipped east along the canals and, later, the railroads (Callender 1902; Goodrich 1960).

This system of specialization and exchange and the national prosperity it helped to produce did not occur on its own. Because economic and political actors are reluctant to undertake specialized investments that are vulnerable to political change, a stable republican governmental structure underpinned these investments. A host of national and especially state policies also supported this accomplishment. As discussed in the next section, the investments resulting in regional specialization also required complementary action by state governments. The purpose of this chapter is to explain the institutions that promoted this outcome.

We divide the Constitution's effects into three categories. First, the direct effects: making new national policies. Second, the indirect effects: the creation of market-preserving federalism, fostering competition among the 
states, and allowing them to solve a wide range of important political and economic and political problems. And third, the forward-looking effects of problem solving and bargaining. We discuss these in turn.

\subsubsection{Direct Effects: Promotion of New National Policies}

Our discussion of the Constitution's direct effects on national policymaking will be brief, in large part because the other contributions to this volume represent extended investigations into these effects.

We now take American national defense and security for granted, but this is in part because the Founders successfully promoted security (Edling 2003; Hendrickson 2006). As emphasized in section 1.2, providing security proved difficult under the Articles. The national government lacked independent and reliable sources of revenue. It could not retire existing debt or fund new debt if the need arose, it could force the British to honor some provisions of the Treaty of Paris, secure the trans-Appalachian domain, and it had no means to devise strategies for dealing with various problems with foreign governments, such as the closure of British harbors to American merchantmen.

The Constitution helped the new national government solve these problems by granting the national government adequate revenue sources, and by creating a new legislature with sufficient powers to devise new policies and adapt these as circumstances changed.

Working under the new government, political officials solved a range of other important problems that plagued the United States under the Articles. For example, under the Articles, internal trade barriers hindered commerce among the states. Several clauses of the Constitution, notably the commerce clause and privileges and immunities clause, prohibited various types of internal trade barriers by states against the goods and services of other states, fostering a common market central to the growth of specialization and exchange over the next generation. The national government also became the locus of authority of monetary affairs, eliminating another source of conflict (e.g., Rhode Island's inflationary policies whose costs spilled over into other states).

The national government also made new policies in a series of areas dealing with national public goods. Beginning with his landmark Report on Public Credit (1790), Alexander Hamilton helped provide several national public policies necessary to underpin financial markets, including the establishment of public credit (including the assumption of state revolutionary war debts), the national Mint, and the Bank of the United States (Sylla, chapter 2, this volume). The government also established a national post office to improve communications among the states (John 1995). Congress also passed a bankruptcy law, an important institution that lowered both the transactions cost of removing failed enterprises and the incentives for failed enterprises to seek political bailouts. 


\subsubsection{Indirect Effects: A Stable, Centralized Federal System and its Implications}

As Wallis (2007) reminds us, the Constitution did not create the states, and all states had ongoing constitutions in 1787. Adoption of the Constitution did not make the states impotent or secondary players with respect to policy. Indeed, states remained the nexus of economic regulation and the promotion of economic growth. Nor did the Constitution provide a road map for economic and political development.

The Constitution did, however, change the environment in which states operated, inventing a new form of "centralized federalism" that had never existed (Riker 1987). Two important new features of the post-Constitutional environment are relevant for our discussion. First, the most important change was creating a stronger national government capable of policing the common market. The national government had no such powers to prevent states from acting opportunistically under the Articles. The Constitution's commerce clause prevented states from regulating interstate commerce and restricted the federal government to truly national public goods, endowing the United States under the new Constitution with one of the largest common markets in the world.

The second feature was that the Constitution created the conditions of market-preserving federalism (Weingast 1995), matching the economists' prescriptions for fiscal federalism, including competition among subnational jurisdictions (Oates 1972; Tiebout 1956). The importance of market-preserving federalism is that it unleashed the creative engines of state government through competition, all within a common market protected by the federal government.

Federal systems differ across many dimensions, and only some promote fiscal federalism, competition among subnational jurisdictions, and economic development. In addition to a hierarchy of governments, marketpreserving federalism requires four conditions:

- States have power over policies within their jurisdictions, including taxation and the ability to regulate their local economies.

- States participate in a common market.

- States face a hard budget constraint.

- National institutions provide incentives for national officials to honor the rules so that federalism is self-enforcing.

Satisfying these conditions seems natural in the American context, but few modern federal systems meet them (Weingast 1995). ${ }^{7}$ Each of these

7. For example, modern Germany, Mexico, and Russia fail the policy independence condition. Argentina and Brazil fail the hard budget constraint. From 1950 through the early 1990s, India failed the policy independence and self-enforcing conditions (with respect to the latter, the national government used its authority to take over successful opposition state governments). 
conditions is necessary to create effective interjurisdictional competition among the states. States without policy-making authority lack the power to tailor policies to their local environments, so that they cannot design new policies and programs to compete with their rivals. The absence of a common market policed by the national government diminishes the competitive pressures of interjurisdictional competition and allows states to insulate their economy from competitive pressures through internal trade barriers. A soft, as opposed to hard, budget constraint allows states to live beyond their financial means, often ignoring the effects of interjurisdictional competition through the ability to support or bail out noncompetitive local enterprises. Finally, federal systems that are at the discretion of the national government or that fail to prevent that government from manipulating the policies and innovations of subnational governments inhibit competition; for example, when the national government removes governors or governments for policies at variance with those of the national government (as has occurred at times over the last twenty-five years in India, Mexico, and Russia).

For the early United States, the institutions of market-preserving federalism launched the "laboratory of the states." Federalism fostered state experimentation that became critical not only as the competition among the states, but central to the economic growth of the early United States.

We tend to take the new political stability of the national government for granted. But this stability, including the stability of the federal system itself, is necessary for the interregional specialization and exchange necessary to promote prosperity. When states and economic actors feel threatened or believe the system at risk, they are less likely to promote and undertake specialized investments that are vulnerable to political opportunism from other states or the national government.

The main consequence of the Constitution's system of market-preserving federalism is that states developed many of the important policies promoting economic and political development. American states were the frontier of new rights and public goods, including franchise (Sokoloff and Engerman 2000), education (Mariscal and Sokoloff 2000), and party organization (Hofstadter 1969; Holt 1999; North, Wallis, and Weingast 2009, ch. 6). Consider education. In the United States, the leading liberalizers in the nineteenth century were not the original thirteen and wealthier colonies, but new ones (Mariscal and Sokoloff 2000). This pattern arose in part because newer states competed both with each other and with the established states for scarce labor. In order to attract labor to the frontier, states liberalized rights and provided public goods, including education. By midcentury, "more than 40 percent of school-age population in the United States overall was enrolled and nearly 90 percent of white adults were literate" (Mariscal and Sokoloff 2000, 161).

States were also the dominant providers of market-enhancing public goods, especially infrastructure investment and banks to help finance the 
flow of goods and crops to markets, a topic we discuss later (Callender 1902; Goodrich 1960; Wallis and Weingast 2005). They were also the primary locus of economic and social regulation (as Callender [1902]; Handlin and Handlin [1947]; Hartz [1948]; and Hughes [1977] emphasize in different ways). States also controlled the definition and enforcement of most economic property rights, including those pertaining to land and slavery. They were also the principal creators of open access for corporations, with general incorporation acts emerging in the 1840s. Until the Voting Rights Act of 1965 , states were also the primary locus of the regulation and administration of elections (subject to the qualification of the federal experiments during reconstruction). Finally, states collected most direct taxes imposed on citizens (such as the property tax), with the dominant form of national revenue being raised through tariffs.

With respect to the economy, the national government eclipsed the importance of the states only in the mid-twentieth century. Until then, state governments remained the dominant force in taxation, economic regulation, the provision of public goods, and the management of the economy more broadly.

\subsubsection{Some Illustrations of State Promotion of Economic Development}

States in the early republic were remarkably active in the design of markets and the promotion of economic activity. Competition within the framework of market-preserving federalism fostered both state innovation and imitation of successful innovations by others. We illustrate this point with two examples, the evolution of state rules regulating banking and with government promotion of economic development through infrastructure provision.

\section{Banking in the Early United States}

Developing countries often create privileges and rents in the design of new markets (North, Wallis, and Weingast 2009). This is easily seen in banking, where most developing countries restrict the number of banks to limit entry, and sell bank charters as a means of creating economic rents that can be shared among the banks, the government, and specific citizens and firms who receive scarce loans (Haber 2008). Because the government has significant interests in banking, the exchange of privileged rights often explicitly or implicitly grants the government privileged access to loans. Moreover, as Haber (2008) argues, organizing the banking sector in this way limits its ability to provide the basic banking functions of an economy, notably, mobilizing capital to highest valued users who create new enterprises or seek to expand profitable ones. Instead, most loans go to the government, insiders, high government officials, and their relatives. An inevitable consequence of this structure, therefore, is limited competitiveness of the financial sector and, hence, limits on the degree to which banks help foster long-term economic growth. 
The United States was no exception to the rule about restricting entry to create rents shared among bankers and the government. ${ }^{8}$ In 1800 , most states used this system, including Pennsylvania, whose commercial center of Philadelphia was the country's banking center.

States competed in an environment of strong market-preserving federal structure throughout the late eighteenth and nineteenth centuries. Consistent with the previous conditions of market-preserving federalism, states had nearly exclusive regulatory control over markets within their borders, they participated in a common market with product and factor mobility, and they faced a hard budget constraint. Moreover, states raised virtually all of their own revenue. This structure allowed states to design and redesign the rules governing various markets.

In the decade following 1800, Massachusetts slowly switched systems. Beginning with the monopoly approach, it created one large bank, in which it invested heavily, and several smaller banks. The state also imposed a tax on bank capital, which worked against the smaller banks. As the majority owner of the large bank, the state effectively paid part of its own tax. Over time, the state found it raised more taxes from the smaller banks than it did in dividends from the large bank.

The state's fiscal incentives led it to make two changes. It sold its interest in the larger bank, and it stopped limiting entry and selling charters. Under the new system, Massachusetts combined relatively low taxes on bank capital with more open entry into banking. This type of market gave Massachusetts banks a competitive advantage over all other U.S. banks. Merchants, enterprises, and transactions funded in Boston - such as financing, insuring, marketing, and transporting export crops to Europe - had an economic edge over their competitors from other states.

Under the new system, Massachusetts's fiscal incentives differed from those in other states, including Pennsylvania. Because a competitive banking sector maximizes the size of its tax base, Massachusetts now promoted the growth of a competitive banking sector. This system was so successful, that by the early 1830s, Massachusetts had more banks and bank capital than any state in the country. It also received over 50 percent of its revenues from the tax on bank capital, allowing it to reduce the principal tax falling on its citizens, the property tax. This was a win-win policy for that state.

Based on its competitive banking sector, Massachusetts eclipsed Philadelphia as the nation's banking center. A number of years later, New York also switched fiscal systems, emulating Massachusetts, and New York City eclipsed both Boston and Philadelphia as the nation's banking center. Many other states subsequently switched to the system that worked. Had the United States been a centralized federalism, as modern Mexico, the na-

8. Our discussion of banking in the early United States draws on Wallis, Sylla, and Legler (1994) 
tional government would have had little incentive to alter the original system of limited entry once it was in place.

\section{Market-Enhancing Public Goods in the Early Republic}

Early American governments devoted substantial resources to promoting economic development. ${ }^{9}$ Remarkably, state governments, not the national government, played the central role as promoters of development. State financial efforts were nearly an order of magnitude larger than the federal government's. Between 1790 and 1860, state and local governments spent over $\$ 450$ million on transportation improvements; in contrast, the federal government spent $\$ 60$ million (Goodrich 1960).

With millions of acres of fertile land, much of it virgin soil, the early United States was an agrarian economy. Economic growth necessitated investment in both transportation infrastructure (roads, canals, and railroads) to open the frontier to markets, and in banks to finance shipment of goods to markets. State governments financed both large-scale internal improvements and financial institutions (Callender 1903; Goodrich 1960; and Larson 2001). Many of the early projects, such as the Erie Canal, proved immensely profitable for the states.

Importantly, the state and national governments financed development projects in different ways. Congressional politics allowed the national government to finance large collections of small projects (such as lighthouses), but not large projects concentrated in one state or a small number of states (Wallis and Weingast 2005). Congressional majorities would not finance large projects benefiting one or a few states while drawing taxes from the rest. In principle, the national government could have used benefit taxation to solve this problem - raising taxes for the project from the states in proportion to their benefits from the projects - but the constitutional provisions for national taxation prohibited this. To the extent that the national government financed transportation investment, it did so through something-foreveryone programs. In contrast, states financed large projects using benefit taxes, assessing property owners in proportion to their expected economic gains from the new project. This fiscal mechanism allowed them to solve the political problems that plagued the national government.

This pattern of infrastructure finance reveals the incentives underlying the limits on the power of the national government operating in early America. The Constitution created a series of political constraints that made it politically impossible for the federal government to finance large infrastructure projects. Federal efforts came either in the form of financing large collections of small projects, or formal allocation formulas to distribute funds to every state. In short, the national government was politically impotent with respect to the provision of the highest valued infrastructure projects. States filled this gap.

9. This discussion draws on Wallis and Weingast (2005). 


\section{Other Illustrations}

In the same way, states carried out a host of policies, from the form and security of property rights to economic regulation. Moreover, states did not limit creation of rights and promotional policies to commerce. As Sokoloff and Engerman (2000) demonstrate, suffrage represents an interesting case. Virtually all states at the time of independence had property restrictions on the vote. Universal (white) male suffrage tended to emerge on the frontier, as new territories and states sought to be attractive to scarce labor. The innovations of these states, in turn, forced established states to liberalize and remove their suffrage restrictions. Mariscal and Sokoloff (2000) make a similar argument for public education.

\subsubsection{Adaptive Efficiency}

Political stability requires that countries preserve cooperation even as they must adapt to changing circumstances, including various crises. Adaptation, in turn, requires that the different interests in society have a means of finding and implementing bargains that at once solve new problems as they emerge while maintaining cooperation. In particular, all parties with the ability to disrupt the constitutional system - for example, through secession or a coup - must judge themselves better off under the new bargain than disrupting the system. If the constitutional system lacks the ability to make the necessary agreements credible, then the bargaining parties will fail to solve their problems, not because a solution fails to exist, but because they lack the means to find and implement this bargain credibly.

Following Hayek (1960), North (2005) uses the term "adaptive efficiency" to describe a society's ability to solve problems and react to crises within an existing constitutional framework. Mittal (2010) argues that adaptive efficiency reflects the epistemic features of a political system that allow or hinder it to learn and adapt as circumstances require (see also Ober [2008]). Some countries are more likely to weather crises, even if severe. Other countries, such as those in Latin America and Africa, are prone to lapse into disorder and failure in the face of crises. ${ }^{10}$

Adaptive efficiency is one of the central features of the American constitutional system, which has proved relatively adept at allowing Americans to address problems and crises (Mittal 2010). ${ }^{11}$ This adaptability was not inevitable, however. The unanimity requirement under the Articles prevented virtually all adaptation, even in the face of a wide range of debilitating cooperation failures and free-rider problems. Had the Founders merely proposed revisions of the Articles rather than devising a bold, new plan to take its place, it is unlikely that much of the adaptation under the Constitution

10. Using North, Wallis, and Weingast's terminology, these differences in performance reflect differences in limited access versus open access societies.

11. The essays in this volume show how, in a wide range of areas, the American Constitutional structure allowed Americans to devise solutions to a range of policy problems. 
would have occurred. Sequential, piecemeal strengthening of the Articles would have undermined the creation of a truly national government capable of addressing a wide variety of crises and problems.

One of the principal concerns of The Federalist is addressing problems inherent in preserving constitutional stability in periods of unforeseen change. The essays argue that the commitment problem of maintaining an effective federal union is a perpetual one in the sense that it recurs in many guises as circumstances change. Problems of state shirking and disunion are dynamic. To preserve the union given the problems of new circumstances and unforeseen change, the government must possess sufficient power to address a wide variety of threats to cooperative activity over time.

Federalist 23 to 36 argues for the need to create exactly such a capacity to address unforeseen circumstances. Political stability requires an energetic constitution with the power to provide for defense and the people's welfare in unanticipated circumstances.

Constitutions of civil government are not to be framed upon a calculation of existing exigencies, but upon a combination of these with the probable exigencies of ages, according to the natural and tried course of human affairs. Nothing, therefore, can be more fallacious than to infer the extent of any power, proper to be lodged in the national government, from an estimate of its immediate necessities. There ought to be a CAPACITY to provide for future contingencies as they may happen; and as these are illimitable in their nature, it is impossible safely to limit that capacity. (Cooke 1961b, Federalist 34, 210-11)

In designing the Federal Constitution of 1787, America's constitutionmakers recognized that improving the quality of legislative deliberation was central to maintaining political stability. When it came to designing a constitution that would last, they understood that they could not foresee what the future would bring. Rather than leave the future to future generations, they radically reconsidered the role of legislation in society and drew on the latest scientific principles to design a legislative system capable of addressing threats that could not be foreseen.

From the perspective of The Federalist, the legislative process consists of much more than a representative forum - it is the nation's primary means of adaptation, especially in the face of crises. Previous republics tended to conceive of representative bodies more narrowly; for example, granting them veto power to check the power of others who had the power to devise new proposals (such as a nobility in the Italian city-state republics)..$^{12}$ Congress was granted powers sufficient to create new legislation on an ongoing basis.

12. Montesquieu and Machiavelli consider legislatures primarily as rights-protecting institutions, not the adaptive and preference-aggregating forums they were later to become. The $\mathrm{Fed}$ eralist represents a critical transition from a negative, rights-protecting approach to lawmaking to a positive understanding of the role of law of in a changing world. 
This modern legislative form is typical of legislative powers in the developed world today, but it was novel in 1787.

In designing a legislative system to respond to a wide variety of threats, Federalists relied heavily on the leading political science of the day. Liberal incorporation of scientific principles such as competition, redundancy, and diversity in the design of the Federal Constitution suggests that Federalists subscribed to a Humeian view of political science that argued that people, no matter where they are, respond to similar incentives similarly. Implicit in their political science was a response to the challenges of fortuna and uncertainty as they conceived of it.

In order for a single legislative process to adapt to problems of increasing complexity, government officials needed to have constant incentives to search for and create solutions to new and pressing problems that threatened to undermine cooperation. To respond to this challenge, America's constitution-makers designed a political system that puts self-interested elected officials in competition with each other.

Legislative competition is created by concurrent jurisdiction inherent in the separation of powers and federal systems (Federalist 32). Instead of trusting the creation of law to a body of enlightened statesmen, the legislative process involves inputs from many actors embedded in competition (Federalist 10). Within competitive systems, officials in the different institutions invest in expertise to avoid exploitation at the hands of their competitors.

Competition ensures that "ambition counteracts ambition" and inhibits encroachments on the constitutional rules, whether by departmental, federal, or state officials. But competition in the federal and separation of powers systems was not simply created to preserve a set of constitutional limits over time. A complementary goal of intragovernmental competition is to create adaptive efficiency by improving the quality of legislative deliberation, and the ability of legislatures to solve problems as they arise (Mittal 2008). Overlap (or redundancy) in the jurisdiction of these branches creates competitive pressures among them. Competition, in turn, forces each branch not only to check the others, but to invest in skills and knowledge. Competition is also an impetus behind institutional change. By increasing the stock and quality of institutional knowledge (Mokyr 2002), competition in the legislative process improves adaptive efficiency.

In order to respond effectively to unanticipated circumstances, legislative actors need more than political incentives to create legislation that will prove effective in restoring cooperation. They also need the ability to create such legislation. The Federalist framework for adaptive efficiency created a legislative process that restores and reinforces cooperative activity in the face of problems and crises by aggregating, aligning, and codifying knowledge. ${ }^{13}$

13. Focusing on ancient Athens, Ober (2008) articulates the importance of institutions for aggregating, aligning, and codifying knowledge in the success of democratic regimes. 
With regard to aggregation, American constitution-makers sought to ensure that the system as whole would locate effective solutions to new problems. The Federalists sought to widen the epistemic base of government by creating many players with competitive interests in finding legislative solutions. Under the Articles, the unicameral Congress was the sole legislative body. Under the Federal Constitution, two branches of the legislative, the executive, and the judiciary each have a role in creating federal legislation.

In addition to creating many problem-solvers in government, the Constitution created different problem-solvers. Page (2007) uses mathematical modeling to show how groups that display a range of perspectives outperform groups of like-minded experts. He argues that diverse groups of people bring to organizations more and different ways of seeing a problem and, thus, faster and better ways of solving it. ${ }^{14}$ Each branch of the federal government and every state has a distinct culture, experiences and knowledge, and approach to deliberation. The electoral system also contributes to diversity of approach by introducing new representatives with different perspectives into the lawmaking process (Federalist 62).

In addition to aggregating knowledge and producing legislative solutions, it is also critical that the central government coordinate on a legislative solution suited to the problem. In this context, the legislative process is the principal means of aligning a diverse population and set of political institutions on a particular solution to a problem. The required consent of several legislative bodies promoted alignment on moderate proposals. Extreme legislation would pass only in periods with unusual levels of consensus.

Finally, adaptive efficiency requires that solutions to new problems be codified and disseminated quickly. Preserving political stability in a crisis requires that knowledge of the legislative solution be quickly and efficiently dispersed throughout society. Without access to new information, each American state will operate on outdated information-leading to the familiar story of miscalculation, crisis, and disorder. American approaches to codification stem from thoughtful analysis of the Articles of Confederation. Uniformity and clarity in state legislation on issues was a direct response to Madison's concern with the "multiplicity, mutability, and injustice" of state law. Issues of naturalization, trade, and bankruptcy required greater uniformity of treatment and procedure than could be obtained from independent state action.

Our earliest political leaders understood that their work in 1787 would not be perfect (Federalist 85). While a wide variety of threats to cooperative activity could be addressed through legislation, they recognized some situations would require changes to the constitutional framework. With the bitter memory of the Articles' unanimity requirement for amendment fresh

14. Ober (2008) argues that bringing together people with different knowledge and perspectives was part of ancient Athens's success. 
in their minds, the Federalists ensured that amendment of the Federal Constitution could be achieved with greater ease.

Turning to the specifics of adaptation, we have already discussed several ways in which the American system proved adaptive. With respect to western expansion, the American Constitutional framework proved adaptive. The mechanisms for settling western lands and the rules for supervising these units ensured that they would be self-constituting units and that they would be brought into the union on the same terms as existing states (see Grubb, chapter 8 , this volume). This framework limited the potential rent-extraction from existing states and ensured that the new states would enjoy the same incentives possessed by existing states created by the market-preserving federalism environment. As new opportunities arose for expansion, the new nation took advantage of them, such as in the Louisiana Purchase and its settlement.

With respect to financial institutions, the national government promoted aspects of national capital markets, particularly sound public credit and a national bank. Federalism, especially competition among jurisdictions, prompted states to address a range of problems as a means of promoting a healthy economy and outcompeting rivals for scarce capital and labor and for the means of economic prosperity. Notable examples include the banking system and infrastructure to promote economic development. This system was not automatic, however, and often Americans faced seemingly intractable problems.

The most enduring and difficult problem that would episodically trouble Americans over their first century concerned sectional conflict, particularly over slavery. In the nineteenth century, the United States faced five sectional crises; conflicts between Northerners and Southerners over the nature of the Constitution and the future of the republic. In each crisis, the future of the country was at risk, and one - the fourth - resulted in a devastating Civil War when each of the proposed compromises of 1861 failed. With considerable difficulty, Americans solved the other four crises. Those in 1820, 1833,1850 , and 1877 resulted in adaptation of the constitutional bargain through an official Compromise, congressional acts that typically resolved the immediate issue of the crisis but also set rules governing future policies.

None of these compromises officially amended the Constitution. Yet each of the four compromises changed the rules of the political game, resulting in what Eskridge and Ferejohn (2001) call "super-statutes." These statutes represent more than ordinary legislation and can therefore be thought of as small " $\mathrm{c}$ " constitutional changes, changes in the structure of the bargain underlying the political system.

From the beginning of the republic, Americans had to confront the issue of whether one section, North or South, would gain the ability to dominate the national government. This issue underlay each of the five nineteenthcentury crises. Americans constructed the Constitution to balance the interests of the sections so that neither would dominate (Ellis 2000; Finkelman 
1996; Rakove 1996). In particular, it provided a range of credible commitments to protect slavery, including federalism's decentralization of property rights to states, and the three-fifths clause granting Southerners additional representation in Congress based on their slaves.

Perhaps the most important credible commitment to protect slavery was the balance rule, the idea that the country would maintain an equal number of free and slave states (Weingast 1998, 2002). Sectional balance provided each section with a veto over national policy-making through equal representation in the Senate; in particular, it granted Southerners the ability to veto any national legislation over slavery. Sectional balance first emerged with the admission of Kentucky (1792) and Tennessee (1796), bringing each section's delegation up to eight states. Americans maintained this balance through 1850 with the lone admission of California. Attempts to restore balance over the next decade (for example, the Kansas-Nebraska Act in 1854, and the 1858 attempt to admit Kansas as a slave state under the Lecompton constitution that was mired in allegations of voter fraud) added to the crisis.

A critical feature of sectional balance as a major institutional protection for slavery is that it required the two sections to grow in parallel, in turn requiring that each section have sufficient territory within which to expand. Three of the four antebellum crises emerged in moments when one section potentially had an edge, as in 1819 to 1820,1846 to 1850 , and 1854 to 1861 .

As an example, consider the Compromise of 1820 . The immediate concern in the 1819 controversy over Missouri was whether to admit Missouri as a slave state. With no obvious free territory looming in the wings, this admission would have tipped the balance in favor of the South, and Northerners reacted in the House of Representatives (where they had a majority) by admitting Missouri subject to conditions of gradual emancipation of all slaves. Southerners used their equal representation in the Senate to prevent this provision from becoming law, and a crisis ensued.

The Compromise of 1820 resolved the crisis on three different levels. First, it admitted Maine (broken off from Massachusetts) as a free state to balance the admission of Missouri, maintaining sectional balance. Second, it divided the remaining territories between free and slave, removing ambiguity as to their status and the uncertainty over the future disposition of those territories and the resulting states. Third, the Compromise made explicit the balance rule for the future admission in states. For the next three decades, states were admitted in pairs (Arkansas and Michigan in the mid1830s; Florida, Texas, Iowa, and Wisconsin in the mid-1840s). In similar ways, Congress passed compromises in 1833 and 1850 to resolve crises over sectional issues.

In all four antebellum crises, secession and the potential failure of the American Constitution and democracy were live issues, as demonstrated by the secession winter of 1860 to 1861 and the following Civil War. Ameri- 
can constitutional stability, therefore, rested on the ability of Americans to resolve their differences and to provide solutions to new problems as they arose.

Thinking broadly to include federalism and the engine of competition among the states, the Constitution created a framework within which Americans could resolve most of their problems, including the most vexing one of slavery and the balance between the two sections within the Union. Although this framework failed to create a solution in 1861, the constitutional system did allow Americans to resolve their conflicts for three generations prior to the Civil War. This framework provided the basis for ongoing cooperation between the sections, and to foster specialization and exchange of a growing economy. In addition, twenty-five years after the start of the Civil War, Southern states had been readmitted on roughly the same terms as they had left, with the major change being the abolition of slavery.

\subsection{Conclusions}

The most striking contribution of the Constitution - and one too often taken for granted - was the creation of a successful, stable, republican government capable of adapting to the wide variety of changes future generations would face. Without this accomplishment, the United States is unlikely to have achieved its long-term history of sustained economic growth. In contrast to the Articles, which provided incentives for states to shirk their responsibilities, the Constitution created a system in which Americans cooperated to solve a range of problems.

In the Constitution's first decade, new policies addressed a range of problems, most notably the policy failures under the Articles: providing security for the new nation; addressing a wide range of problems of public finance, including raising sufficient revenue, retiring existing debt, and creating the basis for new debt when needed; asserting control over the frontier; trade policies aimed at the flooding of foreign goods on the American markets and the closing of foreign ports to American shipping; enforcing provisions of the Treaty of Paris; and limiting a range of problems among the states, such as internal trade barriers.

The Constitution also provided the means and incentives for Americans to solve new problems as they arose. Many solutions occurred directly through congressional policy-making. We illustrated this point with the various compromises aimed at solving the episodic problems that arose around slavery, the territories, and westward expansion. The Constitution also created indirect incentives for Americans to solve their problems through the marketpreserving federalism. States not only had incentives to create strong systems of property and other rights as a means of competing against neighboring states, but to adapt their policies and institutions as circumstances changed. With respect to banks, for example, states originally created a system of 
local monopolies; but gradually, following the innovations in Massachusetts, states moved to a system of competitive banking. By the Civil War, the United States had more banks than any other economy. Competition among the frontier territories and states for scarce capital and especially labor led them to expand political rights and education, resulting in universal enfranchisement, at least for white males.

The result was one of the biggest common markets in the world, largely free of government regulation. In combination, the national and state governments provided a secure environment for investment with a relative absence of political opportunism or threat of expropriation. Significant specialization and exchange resulted, producing long-term economic growth.

\section{References}

Buel, R. 1980. Dear liberty: Connecticut's mobilization for the revolutionary war. Middletown, CT: Wesleyan University Press.

Callender, G. S. 1902. The early transportation and banking enterprises of the states in relation to the growth of corporations. Quarterly Journal of Economics 17 (1): $111-62$.

Cooke, J. E., ed. 1961a. Federalist 10. In The Federalist, Alexander Hamilton, James Madison, and John Jay, 59. Middletown, CT: Wesleyan Press.

. 1961b. Federalist 34. In The Federalist, Alexander Hamilton, James Madison, and John Jay, 210-11. Middletown, CT: Wesleyan Press.

Edling, M. 2003. A revolution in favor of government: Origins of the U.S. Constitution and the making of the American state. New York: Oxford University Press.

Einhorn, R. 2006. American taxation, American slavery. Chicago: University of Chicago Press.

Ellis, J. J. 2000. Founding brothers: The revolutionary generation. New York: Alfred A. Knopf.

Eskridge, W. N., and J. Ferejohn. 2001. Super-statutes. Duke Law Journal 50 (5): 1215-76.

Farrand, M. 1966. The records of the Federal Convention of 1787. New Haven: Yale University Press.

Finkelman, P. 1996. Slavery and the founders: Race and liberty in the age of Jefferson. Armonk, NY: M. E. Sharpe.

Ford, W. C., ed. 1904-37. Proposed Amendments to the Articles of Confederation, August 7, 1786. Report of Continental Congress. In Journals of the Continental Congress, 1774-1789, journal 31: 494. Washington, DC: Government Printing Office.

Goodrich, C. 1960. Government promotion of canals and railroads, 1800-1890. New York: Columbia University Press.

Haber, Stephen. 2008. Political institutions and financial development: Evidence from the political economy of bank regulation in the United States and Mexico. In The political economy of financial development. Edited by Stephen Haber, Douglass C. North, and Barry R. Weingast. Stanford: Stanford University Press.

Handlin, O., and M. Handlin. 1947. Commonwealth: A study of the role of govern- 
ment in the American economy, Massachusetts, 1774-1861. New York: New York University Press.

Hartz, L. 1948. Economic policy and democratic thought: Pennsylvania, 1776-1860. Cambridge, MA: Harvard University Press.

Hayek, F. A. 1960. The Constitution of liberty. Chicago: University of Chicago Press.

Hendrickson, D.C. 2006. Peace pact: The lost world of the American founding. Lawrence, KS: University Press of Kansas.

Hofstadter, R. 1969. The idea of a party system. Berkeley: University of California Press.

Holt, M. F. 1999. The rise and fall of the American Whig Party: Jacksonian politics and the onset of the Civil War. New York: Oxford University Press.

Holton, W. 2007. Unruly Americans and the origins of the Constitution. New York: Hill and Wang.

Hughes, J. 1977. The governmental habit. New York: Basic.

John, R. R. 1995. Spreading the news: The American postal system from Franklin to Morse. Cambridge, MA: Harvard University Press.

Kammen, M. G. 1986. A machine that would go of itself: The Constitution in American culture. New York: Knopf.

Landau, M. 1969. Redundancy, rationality, and the problem of duplication and overlap. Public Administration Review 29 (4): 346-58.

1973. Federalism, redundancy, and system reliability. Publius 3 (2): 173-96.

Larson, J. L. 2001. Internal improvement: National public works and the promise of popular government in the early United States. Chapel Hill: University of North Carolina Press.

Madison, J. 1787. Vices of the political system of the U. States. In James Madison: Writings, ed. Rakove, 69-79. New York: Library of America.

Mariscal, E., and K. L. Sokoloff. 2000. Schooling, suffrage, and the persistence of inequality in the Americas, 1800-1945. In Political institutions and economic growth in Latin America: Essays in policy, history, and political economy, ed. S. Haber, 159-218. Stanford: Hoover Institution Press.

Marks, F. W., III. 1986. Independence on trial: Foreign affairs and the making of the Constitution. Wilmington, DE: Scholarly Resources.

McDonald, F. 1985. Novus ordo seclorum: The intellectual origins of the Constitution. Lawrence, KS: University Press of Kansas.

Mittal, S. 2008. A necessary precaution: The separation of powers and political stability. Paper presented at the annual meeting of the MPSA Annual National Conference, Chicago, April.

- 2010. Constitutional stability in a changing world: Institutions, learning, and adaptive efficiency. Stanford University, Department of Political Science. Working Paper.

Mokyr, J. 2002. The gifts of Athena: Historical origins of the knowledge economy. Princeton, NJ: Princeton University Press.

Nelson, E. 2004. The Greek tradition in republican thought. Cambridge: Cambridge University Press.

North, D.C. 1961. The economic growth of the United States: 1790-1860. New York: W.W. Norton.

2005. Understanding the process of economic change. Princeton, NJ: Princeton University Press.

North, D.C., J. J. Wallis, and B. R. Weingast. 2009. Violence and social orders: A conceptual framework to interpret recorded human history. Cambridge: Cambridge University Press.

Oates, W. 1972. Fiscal federalism. New York: Harcourt Brace Jovanovich. 
Ober, J. 2008. Democracy and knowledge: Innovation and learning in classical Athens. Princeton, NJ: Princeton University Press.

Onuf, P. S. 1983. The origins of the federal republic: Jurisdictional controversies in the United States, 1775-1787. Philadelphia: University of Pennsylvania Press.

Page, S. E. 2007. The difference: How the power of diversity creates better groups, firms, schools, and societies. Princeton, NJ: Princeton University Press.

Rakove, J. N. 1979. The beginnings of national politics: An interpretive history of the Continental Congress. New York: Knopf.

1996. Original meanings: Politics and ideas in the making of the Constitution. New York: Knopf.

ed. 1999. James Madison to Caleb Wallace, August 23, 1785. James Madison: Writings. New York: Library of America.

Riker, W. H. 1987. The invention of centralized federalism. In The development of American Federalism, ed. W. H. Riker, 17-42. Boston: Kluwer Academic Publishers.

Siemers, D. J. 2002. Ratifying the republic: Antifederalists and Federalists in constitutional time. Stanford: Stanford University Press.

Sokoloff, K. L., and S. L. Engerman. 2000. Institutions, factor endowments, and paths of development in the New World. Journal of Economic Perspectives. 14 (3): 217-32.

Tiebout, C. 1956. A pure theory of local expenditures Journal of Political Economy 64:416-24.

Wallis, J. J. 2007. American government and the promotion of economic development in the national era, 1790 to 1860. In Government and the American economy. ed. P. Fishback and D.C. North, 148-86. Chicago: University of Chicago Press.

Wallis, J. J., R. E. Sylla, and J. B. Legler. 1994. The interaction of taxation and regulation in nineteenth century U.S. banking. In The regulated economy: A historical approach to political economy, ed. C. Goldin and G. D. Libecap, 121-44. Chicago: University of Chicago Press.

Wallis, J. J., and B. Weingast. 2005. Equilibrium federal impotence: Why the states and not the American national government financed infrastructure investment in the antebellum era. NBER Working Paper no. 11397. Cambridge, MA: National Bureau of Economic Research, June.

Weingast, B. R. 1995. The economic role of political institutions: Market-preserving federalism and economic development. Journal of Law, Economics, and Organization 11 (1): 1-31.

1998. Political stability and civil war: Institutions, commitment, and American democracy. In Analytic narratives, ed. R. Bates, A. Greif, M. Levi, J.-L. Rosenthal, and B. R. Weingast, 148-93. Princeton, NJ: Princeton University Press.

2002. Institutions and political commitment: A new political economy of the American Civil War era. Hoover Institution, Stanford University. Unpublished Manuscript.

Wood, G. S. 1969. The creation of the American republic, 1776-1787. Chapel Hill: University of North Carolina Press. 